\title{
Hawthorn Nectar Enhances Gastrointestinal Motility as Well as Stimulates Intestinal Amylase and Lipase Activities in Mice
}

\author{
Shiyu Zou' ${ }^{1}$, Jiangping Li'1, Chungwah Maㄹ, Jihang Chen², Pou-Kuan Leong², \\ Hoi-Yan Leung', Wing-Man Chan'², Hoi-Shan Wong2, Kam-Ming Ko ${ }^{2 *}$ \\ ${ }^{1}$ Infinitus (China) Company Ltd., Guangzhou, China \\ ${ }^{2}$ Division of Life Science, Hong Kong University of Science and Technology, Hong Kong, China \\ Email: ${ }^{\text {bcrko@ust.hk }}$
}

Received 22 July 2015; accepted 1 September 2015; published 7 September 2015

Copyright (C) 2015 by authors and Scientific Research Publishing Inc.

This work is licensed under the Creative Commons Attribution International License (CC BY). http://creativecommons.org/licenses/by/4.0/

c) (i) Open Access

\begin{abstract}
Gastrointestinal (GI) digestion, which facilitates the decomposition of ingested food into absorbable small molecules for further utilization in the body, necessitates both neural- and hormonalregulated coordination of GI motility and secretion of digestive enzymes in the GI tract. The dysregulation of such coordination is likely associated with a wide range of disorders in the digestive system. Hawthorn Nectar (HN) is a health supplement for improving the wellness of the gastrointestinal digestive system in humans. The ingredients of HN, which include hawthorn, citrus, germinated barley and honeysuckle, are commonly prescribed to increase appetite and to treat digestive disorders in the practice of traditional Chinese medicine. Pharmacological studies have also shown that these herbs can produce beneficial effects on the GI digestive system. In the present study, HN was first examined for its effects on gastric emptying and postprandial intestinal motility in mice. The activities of digestive enzymes in gastric and pancreatic juice were also measured in HN-pretreated mice. Our results showed that long-term HN treatment increased the extents of gastric emptying and postprandial intestinal motility in mice. HN pretreatment also stimulated the activities of intestinal amylase and lipase in mice, while gastric pepsin and intestinal chymotrypsin activities remained unchanged. However, intestinal trypsin activity was suppressed by HN pretreatment. In conclusion, long-term HN consumption may produce beneficial effect on GI digestive function in humans.
\end{abstract}

\section{Keywords}

Hawthorn, Gastrointestinal Digestion, Gastric Emptying, Postprandial Intestinal Motility, Intestinal Amylase, Intestinal Lipase

\footnotetext{
${ }^{*}$ Corresponding author.
}

How to cite this paper: Zou, S.Y., Li, J.P., Ma, C.W., Chen, J.H., Leong, P.-K., Leung, H.-Y., Chan, W.-M., Wong, H.-S. and Ko, K.-M. (2015) Hawthorn Nectar Enhances Gastrointestinal Motility as Well as Stimulates Intestinal Amylase and Lipase Activities in Mice. Chinese Medicine, 6, 159-168. http://dx.doi.org/10.4236/cm.2015.63017 


\section{Introduction}

Gastrointestinal (GI) digestion refers to the process by which ingested food is decomposed into small molecules that can be absorbed and thus provide fuel molecules and build blocks for cellular metabolism in the body [1] [2]. Coordinated GI motility and concerted digestive enzyme secretion are essential to facilitate orderly and complete GI digestion [3]-[7]. GI motility, which mechanically churns ingested food stuff into small pieces, is mediated by the fine-tuned contraction and relaxation of the enteral smooth muscle layers [3]. The orchestrated GI movements can promote the mixing and grinding of food as well as nutrient dispersal and emptying in the GI tract [3]. On the other hand, the chemical digestion of food is dependent on the secretion of a wide range of digestive enzymes, which are in the form of digestive juices, from the auxiliary organs of GI system (such as the pancreas) into the GI tract. Digestive enzymes hydrolyze macronutrients into absorbable small molecules whereas other components in the digestive juices provide optimal conditions for enzymatic reactions [8]. The dysregulation of GI motility and digestive enzyme secretion is likely associated with a wide range of pathological conditions in digestive function, with non-ulcer dyspepsia being one of the most commonly-occurring GI disorders [9]-[11].

Herbal remedies are becoming increasingly popular as alternative treatment for GI disorders. Hawthorn (the fruit of Crataegus pinnatifide Bunge, Crataegus pinnatifida Bunge var. major N. E. Br. and Crataegus cuneata Sieb et Zucc.), citrus (the dried peel of Citrus reticulate), germinated barley (the fruit of Hordei germinatus), and honeysuckle (the flower of Lonicera japonica Thunb, Lonicera confuse D. C., Lonicera hypoglanca Miq. and Lonicerafulvoto mentosa Hsu et S. C. Cheng) are listed in the Chinese Pharmacopoeia (2010) [12] as herbal materials that can be used to promote digestive health. They are commonly consumed for both medicinal and dietary purposes. According to the theory of traditional Chinese medicine, these herbs can produce nourishing effects on digestive organs and are therefore aptly used to increase appetite and to treat digestive disorders such as epigastric distention, diarrhea, abdominal pain as well as relieving symptoms of dyspepsia [13]-[22]. Recently, the pharmacological activities of these herbs on digestive system have also been investigated. Oral administration of the aqueous extracts of hawthorn, citrus and honeysuckle were found to modulate the contractility of the GI tract and thereby improved GI transit and gastric emptying in animal models. The modulatory action of citrus on GI motility was likely mediated by antagonizing muscarinic acetylcholine and serotonin signaling pathways [13]-[15] [17] [19]-[24]. The beneficial effects of hawthorn, citrus, germinated barley and honeysuckle on digestive functions are also manifested in their ability to stimulate digestive enzyme secretion [13]-[24]. Long- term administration of hawthorn was also found to increase the activities of gastric/intestinal peptidase, intestinal amylase and intestinal lipase in mice, whereas citrus and germinated barley were shown to improve carbohydrate and protein digestions through undefined mechanism of actions [13]-[24].

Hawthorn Nectar (HN), which is comprised of hawthorn, citrus, germinated barley and honeysuckle, is a health supplement for improving the wellness of the GI digestive system in humans. In the present study, we investigated the effect of $\mathrm{HN}$ on gastric emptying and postprandial intestinal motility by examining the retention of Evan blue-labeled chyme (partially digested food) in the GI tract of mice. The activities of digestive enzymes in gastric and pancreatic juice were also measured in HN-pretreated mice.

\section{Materials and Methods}

\subsection{Chemicals}

Evans Blue and N-benzoyl-L-tyrosine ethyl ester (BTEE) were purchased from Santa Cruz Biotechnologies (Santa Cruz, CA). Methylcellulose and N- $\alpha$-Benzoyl-DL-arginine-4-nitroanilide hydrochloride (BAPNA) were purchased from Sigma (St. Louis, MO). p-Nitrophenylmyristate was purchased from Wako (Japan).

\subsection{Animal Care}

Male adult ICR mice (provided by the Animal and Plant Care Facility of Hong Kong University of Science and Technology; 30 - 35 g) were randomly assigned into 4 groups, with at least 12 animals in each. ICR mice were intragastrically administered with $\mathrm{HN}$, at daily doses of $3.75,12.5$ and $37.5 \mathrm{~g} / \mathrm{kg}$ (with human equivalent dose being $12.5 \mathrm{~g} / \mathrm{kg}$ ), 5 days per week for 4 weeks (i.e., a total of 20 doses). Control animals received the vehicle (i.e., water) only. Body weight and food efficiency were monitored weekly for mice until sacrifice. Food efficiency was calculated on the basis of the amount of food intake per gram of body weight gained during the course of experiment [25]. Animals were subjected to biochemical analysis $24 \mathrm{~h}$ after the last dosing of HN/ve- hicle. All 
experimental procedures were approved by the Research Practice Committee (Hong Kong University of Science and Technology) (Animal Protocol Approval No. 2013065; Approved Date: 12 November 2013; Experiment Duration: 3 years).

\subsection{Gastric Emptying}

One hundred microliter of Evans blue (at a concentration of $50 \mathrm{mg} / \mathrm{mL}$, dissolved in pre-warmed $0.9 \% \mathrm{NaCl}$ $(\mathrm{w} / \mathrm{v})$ supplemented with $1.5 \%$ methylcellulose) was administered intragastrically in mice. Twenty minutes later, the mice were sacrificed. The stomach was clamped with strings, both above the lower oesophageal sphincter and beneath the pylorus, to prevent leakage of Evans blue. The stomach was then removed with the strings attached and was frozen at $-80^{\circ} \mathrm{C}$ until the measurement of gastric emptying. The extent of gastric emptying was determined spectrophotometrically by measuring the total amount of Evan blue retained in the stomach. The stomach of each individual mouse was excised and then homogenized for 5 complete strokes by a Teflon-in-glass homogenizer in $5 \mathrm{~mL}$ of $0.1 \mathrm{M} \mathrm{NaOH}$. The homogenate was then incubated at room temperature for $1 \mathrm{~h}$ followed by centrifugation at $1400 \times \mathrm{g}$ for $20 \mathrm{~min}$ at $4^{\circ} \mathrm{C}$. The absorbance of the resultant supernatant was measured at $570 \mathrm{~nm}\left(\mathrm{~A}_{570}\right)$. Evan blue content in stomach of mouse sacrificed immediately after intragastric administration of Evan Blue served as standard reference (i.e., complete retention). Percent gastric emptying was estimated by the equation:

$$
\left[\left(A_{57 \text { reference }}-A_{570 \text { sample }}\right) / A_{57 \text { reference }}\right] \times 100 \quad[26]
$$

\subsection{Postprandial Small Intestinal Motility}

Postprandial small intestinal motility was measured by noting the migration of Evans blue from the pylorus to the most distal point of migration 20 min after Evan Blue administration. The extent of Evans blue migration was expressed in percent transit as compared to the total length of the small intestine [27]. The intestine was divided into five equal segments and each of them was sonicated individually in $1 \mathrm{~mL}$ of $0.9 \% \mathrm{NaCl}(\mathrm{w} / \mathrm{v})$ for $1 \mathrm{~h}$. The samples were centrifuged at $1400 \times g$ at $4^{\circ} \mathrm{C}$ for $20 \mathrm{~min}$. The absorbance at $570 \mathrm{~nm}$ of the resultant supernatant was measured. The geometric center of small intestine, which indicates the distribution and distance traveled by Evans blue, was then estimated as follow:

$$
\sum_{n=1}^{5}[(\text { absorbance of segment/total absorbance }) \times n][28]
$$

\subsection{Measurement of Intestinal Digestive Enzyme Activities}

\subsubsection{Preparation of Gastric and Small Intestinal Fluids}

The abdomen of ketamine-anesthetized mouse was incised and the pylorus was clamped with a string. The abdominal incision was then sutured. Mice were sacrificed $2.5 \mathrm{~h}$ after the clamping of pylorus and the gastric fluid was collected by eluting the stomach with $0.7 \mathrm{~mL}$ of $0.9 \%$ saline (w/v) [29] [30]. This procedure was repeated once. Pooled gastric fluid was centrifuged at $600 \times g$ at $25^{\circ} \mathrm{C}$ for $5 \mathrm{~min}$, whereas small intestinal fluid, which was harvested by eluting the small intestine with $5 \mathrm{~mL}$ of $0.9 \% \mathrm{NaCl}(\mathrm{w} / \mathrm{v})$, was also centrifuged. Supernatants of both gastric and intestinal fluids were used for measuring digestive enzyme activities.

\subsubsection{Gastric Pepsin Activity}

Three hundred microliters of $2.5 \%$ hemoglobin (w/v) was pre-incubated with $75 \mu \mathrm{L}$ of $0.3 \mathrm{M} \mathrm{HCl}$ at $37^{\circ} \mathrm{C}$ for 10 min, followed by the addition of $75 \mu \mathrm{L}$ of gastric fluid. For sample blanks, $750 \mu \mathrm{L}$ of $5 \%$ TCA was added. The mixture was incubated at $37^{\circ} \mathrm{C}$ for $10 \mathrm{~min}$. To terminate the reaction, $750 \mu \mathrm{L}$ of $5 \%$ TCA was added to the reaction mixture. The reaction mixture and sample blank were centrifuged at 13,400 $\times g$ for $10 \mathrm{~min}$. Absorbance at $280 \mathrm{~nm}$ of the reaction mixture was measured [31] [32].

\subsubsection{Intestinal Trypsin Activity}

Trypsin activity was assessed using BAPNA as substrate. Twenty millimolar BAPNA was dissolved in dimethyl sulfoxide (DMSO) to make up a stock solution, which was diluted to $1 \mathrm{mM}$ using $50 \mathrm{mMTris-HCl}, \mathrm{pH}$ 8.2. One hundred and eighty microliters of BAPNA solution was added to $20 \mu \mathrm{L}$ of intestinal fluid. Absorbance at $410 \mathrm{~nm}$ 
of the reaction mixture was monitored every 30 seconds at $25^{\circ} \mathrm{C}$ for $10 \min$ [33] [34].

\subsubsection{Intestinal Chymotrypsin Activity}

Chymotrypsin activity was determined using BTEE as substrate. Ninety three microliters of $1.18 \mathrm{mM}$ BTEE [dissolved in 50\% methanol (v/v)] was added to $7 \mu \mathrm{L}$ of intestinal fluid. The mixture was made up to $200 \mu \mathrm{L}$ by assay buffer containing $80 \mathrm{mMTris}-\mathrm{Cl}, 1 \mathrm{mM} \mathrm{CaCl}_{2}, \mathrm{pH} 7.8$. Absorbance at $260 \mathrm{~nm}$ of the reaction mixture was monitored at $37^{\circ} \mathrm{C}$ for $90 \mathrm{sec}$ [35] [36].

\subsubsection{Intestinal Amylase Activity}

Amylase activity was measured by starch-iodine method. Eight microliters of $1 \%$ starch solution (w/v) and $5 \mu \mathrm{L}$ intestinal fluid was incubated at $37^{\circ} \mathrm{C}$ for $30 \mathrm{~min}$. After incubation, $30 \mu \mathrm{L}$ of $1 \mathrm{M} \mathrm{HCl}$ was added. An aliquot $(150 \mu \mathrm{L})$ of iodine reagent $\left(5 \mathrm{mM} \mathrm{I}_{2}\right.$ and $\left.5 \mathrm{mM} \mathrm{KI}\right)$ was added and the reaction mixture was centrifuged at $20,000 \times g$ for $1 \mathrm{~min}$. Absorbance at $600 \mathrm{~nm}$ of the reaction mixture was measured [37].

\subsubsection{Intestinal Lipase Activity}

Intestinal lipase activity was measured using p-nitrophenylmyristate as substrate. Fifty microliter of $100 \mathrm{mM}$ ammonium bicarbonate solution (pH 7.8), $7 \mu \mathrm{L}$ diluted intestinal fluid, $100 \mu \mathrm{L}$ detergent solution (1\% Triton-X 100 in $100 \mathrm{mM}$ ammonium bicarbonate, $\mathrm{pH}$ 7.8) and $8 \mu \mathrm{L}$ of $10 \mathrm{mM}$ p-nitrophenylmyristate (dissolved in absolute ethanol) were incubated at room temperature for $15 \mathrm{~min}$. Absorbance changes at $405 \mathrm{~nm}$ of the reaction mixture was measured at $37^{\circ} \mathrm{C}$ for $15 \mathrm{~min}$ [38]-[40].

\subsection{Statistical Analysis}

All data were expressed as mean \pm standard error of the mean (SEM), unless otherwise specified. Data were analyzed by one-way analysis of variance (one-way ANOVA), unless otherwise specified, and inter-group differences were detected using the Tukey range test, with $p<0.05$.

\section{Results}

Long-term treatment with HN produced no detectable changes in body weight and food efficiency in mice (supplementary material: Figure 1 and Table 1).

Long-term treatment with $\mathrm{HN}$ increased the extent of gastric emptying in mice, with the degree of stimulation being $26 \%$ to $28 \%$ (Figure 1). Long-term administration of HN, at daily doses of 3.75 and $12.5 \mathrm{~g} / \mathrm{kg}$, significantly increased gut motility in a dose-dependent manner, as indirectly indicated by increases in intestinal transit

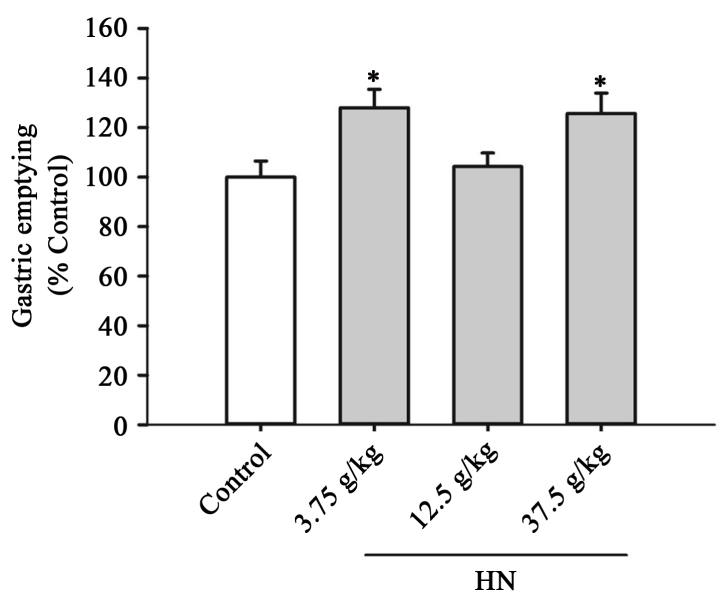

Figure 1. The effect of long-term HN treatment on gastric emptying in ICR mice. The extent of gastric emptying was assessed as described in materials and methods. Data were expressed in percent control with respect to vehicle-treated control [Gastric emptying of control (arbitrary unit) $=52.0 \pm 3.9$ ]. Values given are mean \pm SEM, with $n=5$ to 10 . "Significantly different from vehicle control $(p<0.05)$.

(5\% to 24\%) and intestinal geometric center (6\% to 15\%) (Figure 2(a) and Figure 2(b)). The high dose of HN 
did not produce a detectable change in gut motility (Figure 2).

HN dose-dependently stimulated intestinal amylase and lipase activities, with the extent of increase being $13 \%$ and 44\%, respectively, at $37.5 \mathrm{~g} / \mathrm{kg}$ (Figure 3(d) and Figure 3(e)).While no detectable changes were observed in gastric pepsin and intestinal chymotrypsin activity in $\mathrm{HN}$-pretreated mice, the activity of intestinal trypsin was suppressed by HN pretreatment, with the extent of inhibition being $16 \%$ to18\%, but the suppression was not dose-dependent (Figures 3(a)-(c)).

\section{Discussion}

Results obtained from the present study showed that long-term treatment with HN increased the extent of both gastric emptying and postprandial intestinal motility in mice, as evidenced by the shortened retention time of Evan blue-stained chyme in the GI tract of HN-pretreated mice. Coordinated movements of the stomach and small intestine, which are modulated by both hormonal and neuronal regulation, are required to propel and mechanically break down ingested food in the GI tract [2] [3] [8]. The process also facilitates chemical digestion by mixing ingested food with digestive enzymes in gastric and pancreatic juices [2] [3] [8]. In this regard, abnormalities in the GI motility were associated with impaired digestive functions and a wide variety of GI disorders, among which delayed gastric emptying, also known as gastroparesis, and weak contraction of small intestine was pathological conditions resulting from decreased GI motility [1] [9]-[11]. Patients suffer from the aforementioned impairments in GI function exhibit symptoms such as stagnation with fullness in the chest, abdominal bloating, nausea and reduction in appetite, with the resultant development of malnutrition [9]-[11]. Based on the present experimental findings, HN may therefore be consumed to relief the related GI disorders by virtue of activation of gastric emptying and postprandial intestinal motility. Besides, while there was an increase in the extent of GI motility in HN-pretreated animals, gastric emptying and postprandial intestinal motility were found to show opposing responses towards different doses of HN pretreatment. The observation was likely explained by the feedback control of gastric emptying by the presence of chyme in the duodenum (also known as duodenal brake), jejunum and ileum of the small intestine, which aimed at ensuring complete digestion and nutrient absorption by controlling the entry of chyme into the small intestine [8].

HN pretreatment was also found to stimulate intestinal amylase and lipase activities. This suggests the potential role of HN in improving carbohydrate and fat digestion in the small intestine, which is the major site of food digestion and absorption. The HN-induced activation of intestinal amylase and lipase activities was associated with a slight but significant suppression of intestinal trypsin activity. While transient inhibition of intestinal trypsin activity unlikely produced detectable effect on the digestive function of GI, intestinal trypsin was identified

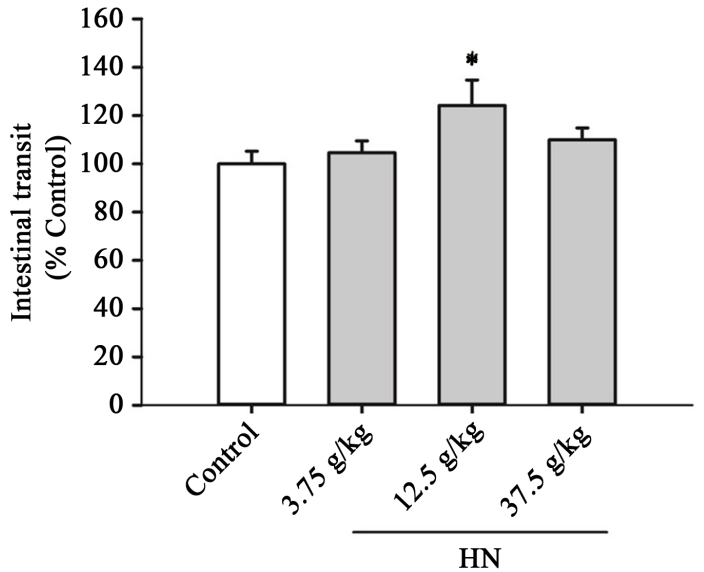

(a)

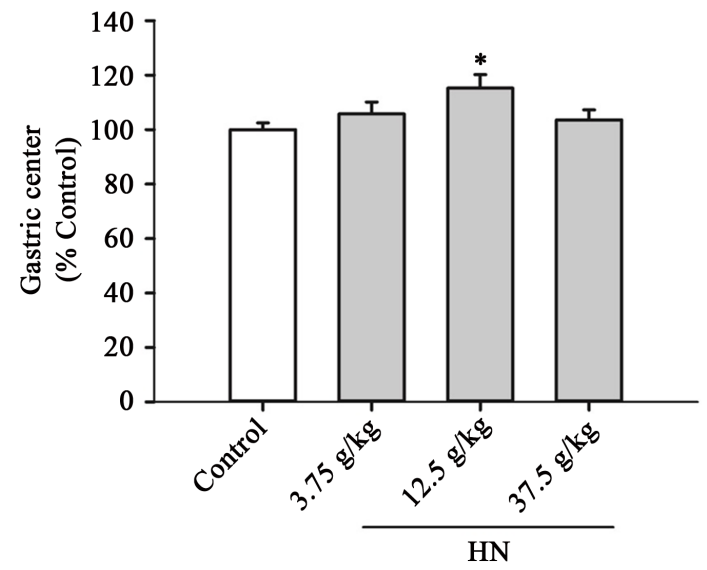

(b)

Figure 2. The effect of long-term HN treatment on postprandial intestinal motility in ICR mice. The extent of postprandial intestinal motility was determined by (a) intestinal transit and (b) intestinal geometric center, as was described in materials and methods. Data were expressed in percent control with respect to vehicle-treated control [Intestinal transit of control = $31.9 \pm 1.9 \mathrm{~cm}$; intestinal geometric center of control $=34.3 \pm 1.2 \mathrm{~cm}]$. Values given are mean \pm SEM, with $n=5$ to 10 . *Significantly different from vehicle control $(p<0.05)$. 


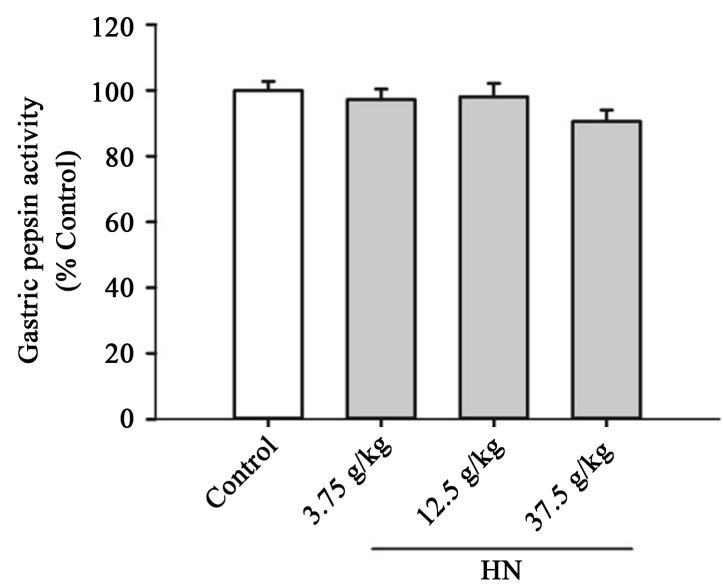

(a)

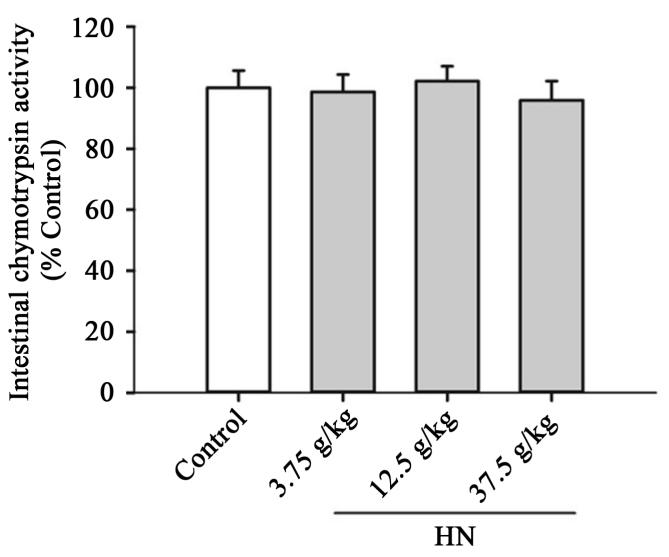

(c)

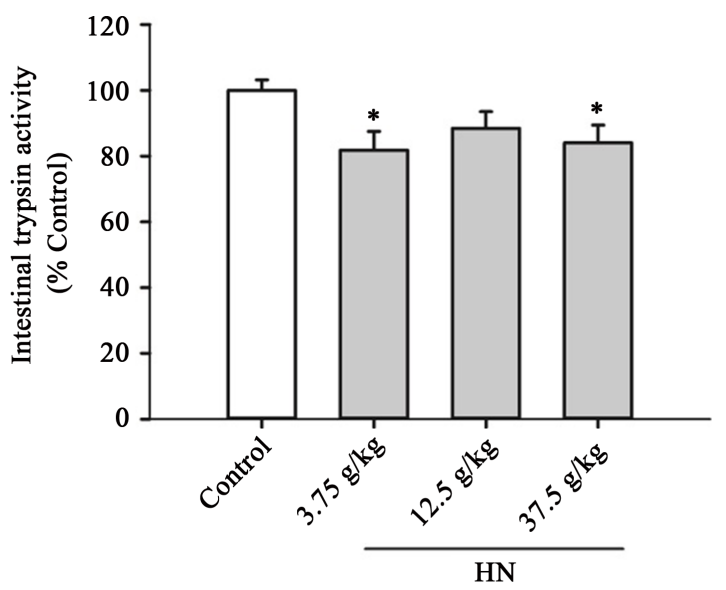

(b)

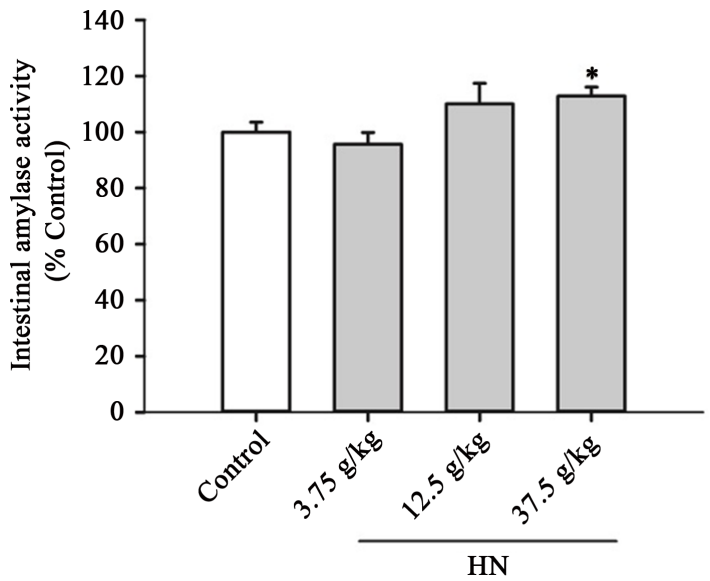

(d)

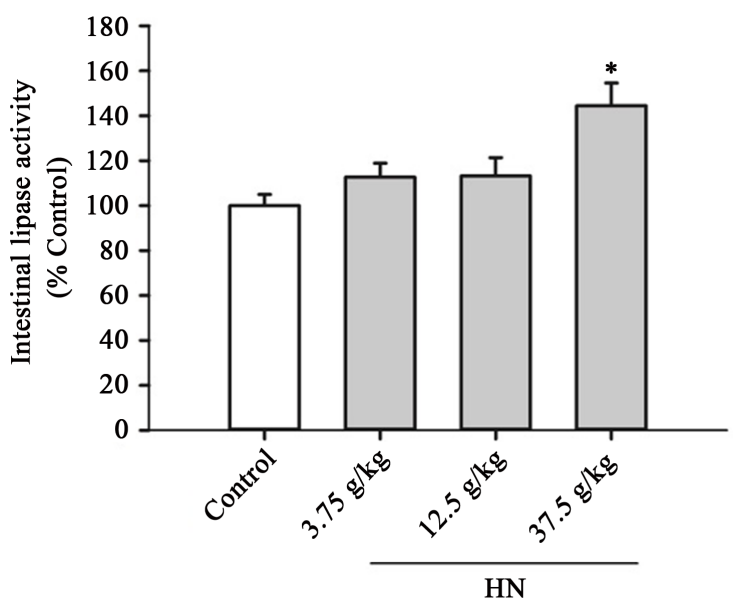

(e)

Figure 3. The effects of long-term HN treatment on gastric/intestinal digestive enzymes activity in ICR mice. (a) Gastric pepsin; (b) Intestinal trypsin; (c) Intestinal chymotrypsin; (d) Intestinal amylase; (e) Intestinal lipase. The activities of gastric and intestinal digestive enzymes were examined as described in materials and methods. Data were expressed in percent control with respect to vehicle-treated control [Enzyme activities of control animals: gastric pepsin $=769.2 \pm 47.3 \mathrm{U} / \mathrm{mg} \mathrm{protein}$; intestinal trypsin $=0.4 \pm 0.0 \mathrm{mU} / \mathrm{mg}$ protein; intestinal chymotrypsin $=11.2 \pm 1.2 \mathrm{mU} / \mathrm{mg}$ protein; intestinal amylase = $3636.1 \pm 392.2 \mathrm{U} / \mathrm{mg}$ protein; and intestinal lipase $=127.5 \pm 10.9 \mathrm{mU} / \mathrm{mg}$ protein]. Values given are mean \pm SEM, with $\mathrm{n}=5$ to 10 . *Significantly different from vehicle control $(p<0.05)$. 
to be one of the key regulators of intestinal digestive enzyme secretion [41] [42]. In this regard, intra-duodenal trypsin or intestinal trypsin perfusion dose-dependently decreased intestinal digestive enzyme secretion by inhibiting the release of cholecystokinin, an intestinal hormone that promoted GI digestion [41] [42]. Therefore, our finding that the $\mathrm{HN}$-induced suppressive effect on intestinal trypsin activity may implicate an increase in the content of digestive enzymes in the small intestine, which is consistent with the beneficial effect of HN pretreatment on GI digestion.

\section{Conclusion}

Long-term treatment with HN increased the extents of gastric emptying and gut motility in mice. While HN pretreatment stimulated intestinal amylase and lipase activities in mice, the gastric pepsin and intestinal chymotrypsin activities remained unchanged. However, the intestinal trypsin activity seemed to be suppressed by HN pretreatment.

\section{References}

[1] O’Keefe, S.J. (1996) Nutrition and Gastrointestinal Disease. Scandinavian Journal of Gastroenterology, 31, 52-59. http://dx.doi.org/10.3109/00365529609094750

[2] Schneeman, B.O. (2002) Gastrointestinal Physiology and Functions. British Journal of Nutrition, 88, S159-S163. http://dx.doi.org/10.1079/bjn2002681

[3] Duke, G.E. (1982) Gastrointestinal Motility and Its Regulation. Poultry Science, 61, 1245-1256. http://dx.doi.org/10.3382/ps.0611245

[4] Stanghellini, V., Ghidini, C., Maccarini, M.R., Paparo, G.F., Corinaldesi, R. and Barbara, L. (1992) Fasting and Postprandial Gastrointestinal Motility in Ulcer and Non-Ulcer Dyspepsia. Gut, 33, 184-190. http://dx.doi.org/10.1136/gut.33.2.184

[5] Drossman, D.A. (1999) The Functional Gastrointestinal Disorders and the Rome II Process. Gut, 45, II1-II5. http://dx.doi.org/10.1136/gut.45.2008.ii1

[6] DeSesso, J.M. and Jacobson, C.F. (2001) Anatomical and Physiological Parameters Affecting Gastrointestinal Absorption in Humans and Rats. Food and Chemical Toxicology, 39, 209-228. http://dx.doi.org/10.1016/S0278-6915(00)00136-8

[7] Whitcomb, D.C. and Lowe, M.E. (2007) Human Intestinal Digestive Enzymes. Digestive Diseases and Sciences, 52, 1-17. http://dx.doi.org/10.1007/s10620-006-9589-z

[8] Kerkut, G.A. (1985) Regulation: Digestion, Nutrition, Excretion. Pergamon Press Ltd., Headington Hill Hall, Oxford.

[9] Koloski, N.A., Talley, N.J. and Boyce, P.M. (2000) The Impact of Functional Gastrointestinal Disorders on Quality of Life. The American Journal of Gastroenterology, 95, 67-71. http://dx.doi.org/10.1111/j.1572-0241.2000.01735.x

[10] Mayer, E.A. and Collins, S.M. (2002) Evolving Pathophysiologic Models of Functional Gastrointestinal Disorders. Gastroenterology, 122, 2032-2048. http://dx.doi.org/10.1053/gast.2002.33584

[11] Choi, M.G. and Jung, H.K. (2011) Health Related Quality of Life in Functional Gastrointestinal Disorders in Asia. Journal of Neurogastroenterology and Motillity, 17, 245-251. http://dx.doi.org/10.5056/jnm.2011.17.3.245

[12] Chinese Pharmacopoeia Commission (2010) Pharmacopoeia of the People's Republic of China 2010. Set of 3, Chinese Edition, China Medical Science and Technology Press, Beijing.

[13] Xu, P. (1998) A Comparative Study of the Pharmacological Activities of Aqueous Extract and Volatile Oil of Citrus. Journal of Jiangxi University of Traditional Chinese Medicine, 10, 172-173.

[14] Zhao, G., Liu, J., Lin, D., Zhang, X. and Wang, H. (2002) Studies on the Chemical Constituents in Floslonicerae. Chinese Traditional Patent Medicine, 24, 973-976.

[15] Luo, Y. and Wang, H. (2004) A Study of the Chemical Composition and Pharmacological Activities of Crataegus. Lishizhen Medicine and Materia Medica Research, 15, 53.

[16] Wang, X., Zhou, J., Jin, X. and Dai, C. (2007) Pharmacological Activities and Clinical Use of Germinated Barley. Chinese Traditional Patent Medicine, 29, 1677-1679.

[17] Zhang, X., Zhan, X. and Wang, X. (2007) The Research Progress of Crataegus. Chinese Modern Medicine, 9, 30-33.

[18] Yang, T., Ceng, Y., Xiao, F., Pu, X., Du, J. and Yang, S. (2007) Research Progress on Medicinal Barley and Its Active Substance. Journal of Triticeae Crops, 27, 1154-1158.

[19] Li, G., Liang, X. and Ge, X. (2009) The Chemical Elements of Hawthorn and Their Health-Care Functions. Jiangsu Condiment and Subsidiary Food, 6, 25-27. 
[20] Kumar, D., Arya, V., Ali Bhat, Z., Khan, N.A. and Prasad, D.N. (2012) The Genus Crataegus: Chemical and Pharmacological Perspectives. Revista Brasileira de Farmacognosia, 22, 1187-1200. http://dx.doi.org/10.1590/S0102-695X2012005000094

[21] Lam, Y. (2012) Progress in Research on the Effects of Pericarpium Citri Reticulatae on Digestive System. Traditional Chinese Medicine, 1, 37-40.

[22] Wu, J., Peng, W., Qin, R. and Zhou, H. (2014) Crataegus pinnatifida: Chemical Constituents, Pharmacology, and Potential Applications. Molecules, 19, 1685-1712. http://dx.doi.org/10.3390/molecules19021685

[23] Ou, X., Lin, Q. and Huang, X. (2004) Research on Gastrointestinal Movement of the Big Fruit Hawthorn in Mice. Journal of Guangxi Traditional Chinese Medical University, 3, 6-9.

[24] Wang, T., An, Y., Zhao, C., Han, L., Boakye-Yiadom, M., Wang, W. and Zhang, Y. (2011) Regulation Effects of Crataegus pinnatifida Leaf on Glucose and Lipids Metabolism. Journal of Agricultural and Food Chemistry, 59, 49874994. http://dx.doi.org/10.1021/jf1049062

[25] Se, N.Y., Sang, J.M., Sung, K.K., Byung, O.I. and Sung, H.C. (2004) Wild Ginseng Prevents the Onset of High-Fat Diet Induced Hyperglycemia and Obesity in ICR Mice. Archives of Pharmacal Research, 27, 790-796. http://dx.doi.org/10.1007/BF02980150

[26] Benedicte, Y.D.W., Albert, J.B., Joris, G.D.M., Tom, G.M., Arnold, G.H. and Paul, A.P. (2002) Effect of Inhibition of Inducible Nitric Oxide Synthase and Guanylyl Cyclase on Endotoxin-Induced Delay in Gastric Emptying and Intestinal Transit in Mice. Shock, 18, 125-131. http://dx.doi.org/10.1097/00024382-200208000-00006

[27] Inge, D., Benedicte, D.W., Theo, T., Joris, D.M., Paul, P. and Theo, P. (2005) Comparison of the Gastroprokinetic Effects of Ghrelin, GHRP-6 and Motilin in Rats in Vivo and in Vitro. European Journal of Pharmacology, 515, 160-168. http://dx.doi.org/10.1016/j.ejphar.2005.04.008

[28] Miller, M.S., Galligan, J.J. and Burks, T.F. (1981) Accurate Measurement of Intestinal Transit in the Rat. Journal of Pharmacological Methods, 6, 211-217. http://dx.doi.org/10.1016/0160-5402(81)90110-8

[29] Hitoshi, T., Chamelli, J., Richard, S. and Glenn, M. (1992) Hypertrophic Gastropathy Resembling Menetrier’s Disease in Transgenic Mice Overexpressing Transforming Growth Factor $\alpha$ in the Stomach. The Journal of Clinical Investigation, 90, 1161-1167. http://dx.doi.org/10.1172/JCI115936

[30] Every, A.L., Ng, G.Z., Skene, C.D., Harbour, S.N., Walduck, A.K., McGuckin, M.A. and Sutton, P. (2011) Localized Suppression of Inflammation at Sites of Helicobacter pylori Colonization. Infection and Immunity, 79, 4186-4192. http://dx.doi.org/10.1128/IAI.05602-11

[31] Nalinanon, S., Benjakul, S. and Kishimura, H. (2010) Purification and Biochemical Properties of Pepsins from the Stomach of Skiphack Tuna (Katsuwonus pelanmis). European Food Research and Technology, 231, 259-269. http://dx.doi.org/10.1007/s00217-010-1275-x

[32] Enzymatic Assay of PEPSIN (EC 3.4.23.1), Sigma Quality Control Test Procedure. Sigma Web.

[33] Roy, D.M. and Schneeman, B.O. (1981) Effect of Soy Protein, Casein and Trypsin Inhibitor on Cholesterol, Bile Acids and Intestinal Enzymes in Mice. Journal of Nutrition, 111, 878-885.

[34] Sharifi, M., Gitgar, M.G., Ghadayari, M. and Ajamhasani, M. (2012) Identification and Characterization of Midgut Digestive Proteases from Rosaceous Branch Borer, Osphranteria coerulescens (Coleoptera: Cerambycidae). Romanian Journal of Biochemistry, 49, 33-47.

[35] Castillo-Yáñez, F.J., Pacheco-Aguilar, R., García-Carreño, F.L. and Navarrete-Del, T.M.L. (2005) Isolation and Characterization of Trypsin from Pyloric Caeca of Monterey Sardine Sardinops sagax caerulea. Comparative Biochemistry and Physiology, Part B: Biochemistry \& Molecular Biology, 140, 91-98. http://dx.doi.org/10.1016/j.cbpc.2004.09.031

[36] Thompson, S., Fawcett, M.C., Pulman, L.B. and Self, C.H. (2006) A Simple Procedure for the Photoregulation of Chymotrypsin Activity. Photochemical \& Photobiological Sciences, 5, 326-330. http://dx.doi.org/10.1039/b515146e

[37] Xiao, Z., Storms, R. and Tsang, A. (2006) A Quantitative Starch-Iodine Method for Measuring Alpha-Amylase and Glucoamylase Activities. Analytical Biochemistry, 351, 146-148. http://dx.doi.org/10.1016/j.ab.2006.01.036

[38] German, D.P., Horn, M.H. and Gawlicka, A. (2004) Digestive Enzyme Activities in Herbivorous and Carnivorous Prickleback Fishes (Teleostei: Stichaeidae): Ontogenetic, Dietary, and Phylogenetic Effects. Physiological and Biochemical Zoology, 77, 789-804. http://dx.doi.org/10.1086/422228

[39] Gawlicka, A., Parent, B., Horn, M.H., Ross, N., Opstad, I. and Torrissen, O.J. (2000) Activity of Digestive Enzymes in Yolk-Sac Larvae of Atlantic Halibut (Hippoglossus hippoglossus): Indication of Readiness for First Feeding. Aquaculture, 184, 303-314. http://dx.doi.org/10.1016/S0044-8486(99)00322-1

[40] O’Brien-MacDonald, K., Brown, J.A. and Parrish, C.C. (2006) Growth, Behavior, and Digestive Enzyme Activity in Larval Atlantic Cod (Gadus morhua) in Relation to Rotifer Lipad. ICES Journal of Marine Science, 63, 275-284. http://dx.doi.org/10.1016/j.icesjms.2005.11.017 
[41] Owyang, C., Louie, D.S. and Tatum, D. (1986) Feedback Regulation of Intestinal Enzyme Secretion. Suppression of Cholecystokinin Release by Trypsin. Journal of Clinical Investigation, 77, 2042-2047. http://dx.doi.org/10.1172/JCI112534

[42] Owyang, C., May, D. and Louie, D.S. (1986) Trypsin Suppression of Intestinal Enzyme Secretion. Differential Effect on Cholecystokinin Release and the Enterointestinal Reflex. Gastroenterology, 91, 637-643. 


\section{Supplementary Materials}

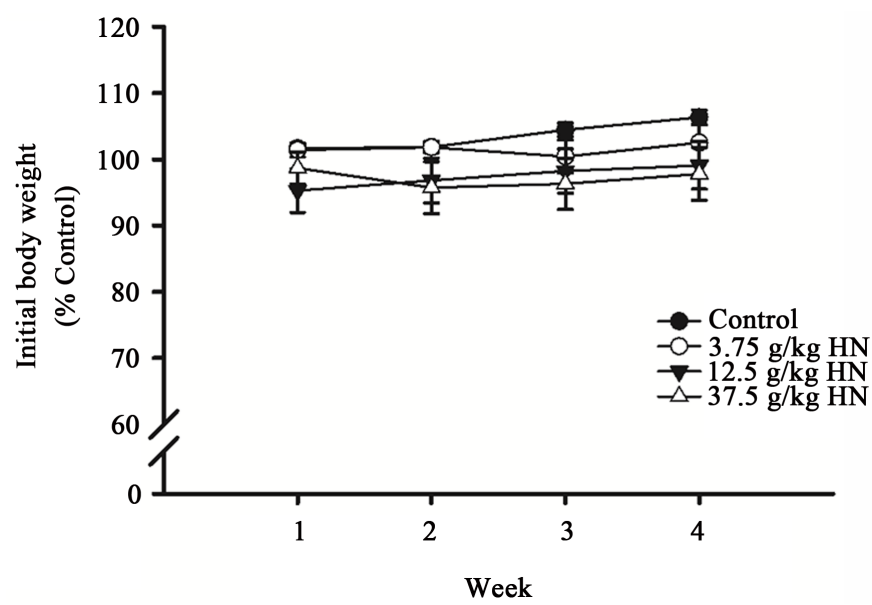

Figure 1. Long-term HN treatment on the body weight in ICR mice. Body weight changes in vehicle- and HN-treated ICR mice were monitored weekly throughout the course of vehicle/HN treatment. Data were expressed in percent control with respect to initial body weight [control initial body weight $(\mathrm{g})=41.8 \pm 2.5$ ]. Values given are mean \pm SEM, with $\mathrm{n}=5$ to 10 .

Table 1. The effect of long-term HN treatment on food efficiency in ICR mice.

\begin{tabular}{ccccc}
\hline & \multicolumn{3}{c}{ Week } \\
Treatment & 1 & 2 & 3 & 4 \\
\cline { 2 - 5 } Control & $0.010 \pm 0.006$ & $0.003 \pm 0.007$ & $0.022 \pm 0.004$ & $0.013 \pm 0.003$ \\
$3.75 \mathrm{~g} / \mathrm{kg}$ & $-0.001 \pm 0.009$ & $0.012 \pm 0.007$ & $0.011 \pm 0.006$ & $0.016 \pm 0.010$ \\
$12.5 \mathrm{~g} / \mathrm{kg}$ & $-0.007 \pm 0.006$ & $0.012 \pm 0.007$ & $0.013 \pm 0.008$ & $0.004 \pm 0.009$ \\
$37.5 \mathrm{~g} / \mathrm{kg}$ & $0.003 \pm 0.008$ & $0.016 \pm 0.002$ & $0.005 \pm 0.000$ & $0.009 \pm 0.001$ \\
\hline
\end{tabular}

The amount of food intake of mice was monitored weekly until sacrificed. Food efficiency was calculated based on the amount of food intake per gram of body weight gained during the course of the experiment, with $n=5$ to 10 . 